\title{
INTEGRATED LAW ENFORCEMENT (GAKKUMDU) IN MANAGING GENERAL ELECTIONS IN INDONESIA
}

\author{
RidwanArifin ${ }^{1}$, Dasri ${ }^{2}$ \\ ${ }^{1}$ Faculty of Law, UniversitasNegeri Semarang (UNNES) \\ K Building $1^{\text {st }}$ Floor, Sekaran Campus, Gunungpati, Semarang, 50229 \\ Email: ridwan.arifin@mail.unnes.ac.id \\ ${ }^{2}$ Faculty of Law, UniversitasNegeri Semarang (UNNES) \\ Email: dasrifeb15@gmail.com
}

\begin{abstract}
The number of general elections in Indonesia, such as in regional head elections, leagislative elections and in the election of president and vice president. In general elections, the president and vice president are often referred to as legislative elections, while the head of the region itself has the title, namely regional head elections only. The proverb says that where there is a rule there will be an offense. Therefore, to avoid any undesirable things, an improvement is needed to deal with this. In order to avoid fraud, in the improvement there is certainly an institution that regulates, namely from the law apparatus, as an apparatus in law enforcement is required to be able to ensure the existence of violations in the implementation of elections only because solely to enforce integrated law. In fact, the general election is always interesting so that it can be investigated, which is contained in the rules, implementation, and in the participants and the community. It certainly determines the success of the general election. If the rules are already felt or considered to be good in its implementation without capable law enforcement so that it will be difficult also in its realization. Good rules and good law enforcers also cannot maximize if the people themselves are ignorant and do not care about existing regulations. So, order between the three of them bound each other. In general elections it does not only involve one or two people, but requires a lot of people, so that the community is required to participate in issuing their opinions. But with so many parties participating in the election, there were many violations of the implementation, for example in 2014, where there were still many violations in general elections. Whereas at that time there was a socialization of the implementation of the general election which was socialized by the KPU and Bawaslu, not only socialization but also from the Bawaslu and its staff who participated in efforts to prevent the occurrence of violations in general elections. Although in the end socialization in prevention still cannot reduce the number of violations that exist. In dealing with this problem the creation of a system can reduce violations during the election, namely the process of synergy of Gakkumdu with the aim of realizing democratic elections in 2019 in the hope that it can provide the effect of clarity and change in carrying out general elections.
\end{abstract}

Keywords: implementation, enforcement, change and selection 


\begin{abstract}
Abstrak: Jumlah pemilihan umum di Indonesia, seperti dalam pemilihan kepala daerah, pemilihan leagislatif dan dalam pemilihan presiden dan wakil presiden. Dalam pemilihan umum, presiden dan wakil presiden sering disebut sebagai pemilihan legislatif, sedangkan kepala daerah sendiri memiliki gelar, yaitu pemilihan kepala daerah saja. Pepatah mengatakan bahwa di mana ada aturan akan ada pelanggaran. Oleh karena itu, untuk menghindari hal-hal yang tidak diinginkan, diperlukan perbaikan untuk mengatasi hal ini. Untuk menghindari kecurangan, dalam perbaikan pasti ada lembaga yang mengatur, yaitu dari aparat hukum, karena aparat dalam penegakan hukum dituntut untuk dapat memastikan adanya pelanggaran dalam pelaksanaan pemilu hanya karena semata-mata untuk menegakkan hukum terintegrasi. Bahkan, pemilihan umum selalu menarik sehingga bisa diselidiki, yang terkandung dalam aturan, pelaksanaan, dan di peserta dan masyarakat Hal itu tentu menentukan keberhasilan pemilihan umum. Jika aturan tersebut sudah dirasakan atau dianggap baik dalam implementasinya tanpa mampu penegakan hukum sehingga akan sulit juga dalam realisasinya. Aturan yang baik dan penegak hukum yang baik juga tidak bisa maksimal jika orang itu sendiri tidak tahu dan tidak peduli dengan peraturan yang ada. Jadi, ketertiban di antara mereka bertiga saling mengikat. Dalam pemilihan umum itu tidak hanya melibatkan satu atau dua orang, tetapi membutuhkan banyak orang, sehingga masyarakat dituntut untuk berpartisipasi dalam mengeluarkan pendapat mereka. Tetapi dengan begitu banyak partai yang berpartisipasi dalam pemilu, ada banyak pelanggaran implementasi, misalnya pada tahun 2014, di mana masih banyak pelanggaran dalam pemilihan umum. Sedangkan pada saat itu ada sosialisasi pelaksanaan pemilihan umum yang disosialisasikan oleh KPU dan Bawaslu, tidak hanya sosialisasi tetapi juga dari Bawaslu dan stafnya yang ikut serta dalam upaya mencegah terjadinya pelanggaran dalam pemilihan umum. Meskipun pada akhirnya sosialisasi pencegahan masih belum bisa mengurangi jumlah pelanggaran yang ada. Dalam menghadapi masalah ini penciptaan suatu sistem dapat mengurangi pelanggaran selama pemilu, yaitu proses sinergi Gakkumdu dengan tujuan mewujudkan pemilu yang demokratis pada tahun 2019 dengan harapan dapat memberikan efek kejelasan dan perubahan dalam pelaksanaan umum pemilihan umum.
\end{abstract}

Kata kunci: implementasi, penegakan, perubahan dan seleksi

\section{BACKGROUND}

It is impossible if there is still no democratic country in the all-time era or can be said to be the age of now as it is now in organizing an electoral movement, in a democratic country the election is an agreement in forming an institutional community. The General Election can be said as a means for the public to issue their voice directly or can choose a leader according to their heart that can bring to life the prosperous community. No wonder if the implementation of general elections requires an improvement. There have been many elections held in countries, especially Indonesia, but in the implementation of a procedure in the election they are always prioritized in order to create a democracy that can work well in the absence of a violation.

Replacement of Law No. 10 of 2008 concerning Elections (general election) Members of the People's 
Legislative Assembly, Regional Representative Council, and Regional People's Representative Council are required to improve the electoral system of the House of Representatives, Regional Representatives and Regional Representatives as actualization of state and government life based on the principles of democracy and improving the quality of the holding of elections from time to time consistently. In this case the government has issued Law No. 8 of 2012 which refers to elections (general elections) and the House of Representatives and the Regional Representative Council, which also regulates criminal offenses in general elections. Election criminal acts, namely all criminal acts relating to the implementation of elections that are regulated in the Election Law. Election crime in Indonesia in its development experienced many changes in the form of increasing the types of criminal acts to the difference between the addition of criminal sanctions. This can make criminal acts from day to day more and more serious attention because the measure of the success of democratic countries can be seen from their success in holding elections. Finally, the government tightened the legal rules regarding election crime by further aggravating criminal sanctions for perpetrators. In the bookkeeping of the 1945 Constitution states that Indonesia is a country based on law, then any criminal act that occurs should be processed through legal process, so that law is seen as the only means for resolving a criminal act. Crime is an action that is not only formulated by the Criminal Code as a crime or criminal act. ${ }^{1}$

According to Moeljatnohimself said that criminal acts are acts that are prohibited by a legal regulation which is accompanied by threats (sanctions) in the form of certain crimes. ${ }^{2}$ To be able to effectively handle cases of electoral violations involving criminal matters, the Election Supervisory Committee, the police, and the prosecutor's office form the so-called Integrated Law Enforcement Center (Sentra Gakkumdu), as a legal agreement between the Attorney General of the Republic of Indonesia, the Indonesian National Police Chief and the Chairperson of Election Supervisory Body General. The membership of the Gakkumdu Center at the central level consists of the National Police Kabareskrim, the Junior Attorney General for General Crimes and the Chairperson of

\footnotetext{
$1 \quad$ S.R. Sianturi, Asas-asasHukumPidana di Indonesia danPenerapannya, Jakarta: StoriaGrafika, 2002, p. 204.

2 C.S.T. Kansildan Christine S.T. Kansil, PokokpokokHukumPidana,Jakarta: Pradnya, Paramita, 2004, p. 54.
} 
the Election Election Handling Division. While at the provincial level itself consists of Director of Criminal / General Affairs, High Prosecutor General Criminal Assistant, Coordinator of Legal Affairs and Management of Provincial Panwaslu Election Violations, and at the district / city level the members are Head of Criminal Investigation Unit, Head of General Criminal Section and Coordinator of Legal Affairs and Management of District / City Panwaslu Election Violations. If elections are won through malpractices, it is difficult to say that the leader of the Regional Head is people's representatives. $^{3}$

If we talk about elections, then surely we will also discuss the implementation of elections, because the implementation of the election aims to be formed so that it can overcome all activities or implementation in elections. Which of them can be in preparing for a need in the implementation of elections, as well as regulating the course of the election and can be disciplined in the implementation of elections. The holding of an election active in the field or commonly referred to as KPU and Bawaslu, as stipulated in Law Number 15 of 2011 states that the Field Election Supervisor is an officer formed by the

3 TopoSantoso, TindakPidanaPemilu, Jakarta, SinarGrafika, 2006, p. 5.
District Election Supervisory Committee who is in charge of overseeing the implementation of General Elections in the village or kelurahan. ${ }^{4}$ The task of the Field General Election Supervisor as contained in the provisions of Law Number 15 of 2011 is to carry out the tasks assigned by the Election Supervisory Board to him which is the same as the duties of the General Election Supervisory Board. ${ }^{5}$ Where the KPU itself is a body in organizing in general elections that has the task of preparing everything needed for general elections to run according to what is desired, while the Election Supervisory Board is the organizer who plays an active role in the election, namely in an investigation and acceptance report on various violations when carrying out general elections.

Every time the implementation of the Election always raises many issues regarding the weakness of electoral law enforcement. Issues like this start from the reality of how many violations such as administration and criminal offenses that are not handled thoroughly. In addition, the instruments in the existing electoral

\footnotetext{
4 Article 1 (20), Undang-UndangNomor 15 Tahun 2011 TentangPenyelenggaraanPemilihanUmum

5 Article 81, Undang-UndangNomor 15 Tahun 2011

TentangPenyelenggaraanPemilihanUmum
} 


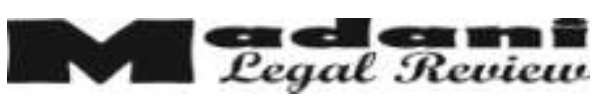

legislation have not regulated objections to the decision of the election organizers. ${ }^{6}$

The number of problems related to election results or those not related to election results, for example such as administrative violations, disputes and election crimes, which are the basis for consideration of the establishment of Integrated Law Enforcement institutions or institutions (GAKKUMDU) which directly involve 3 (three ) institutions namely the Republic of Indonesia National Election Supervisory Body (Bawaslu), the Republic of Indonesia National Police (Polri), and the Republic of Indonesia Attorney General in their level up to the Provinces and Districts / Cities, which began since the election of DPR, DPD and DPRD Members in 2004 until the 2014 Election of Members of the DPR, DPD and DPRD. ${ }^{7}$

The establishment of the Gakkumdu Center from the central to the Regency / City level is expected to be able to realize an integrated, simple, fast and impartial election law enforcement law. Based on the evaluation of handling electoral violations committed by Bawaslu against the Election Supervisors at the provincial and regency / city levels in 2014, it was found that there were still perceptual inequalities in the application of articles in the criminal provisions

Ibid.

Ibid. p. 108. stipulated in the Election Law. For example, related to the implementation of campaigns outside the schedule, and so on. In addition there is also a problem that is faced, namely the existence of direct rejection by the police when forwarding the recommendations of alleged criminal offenses by the election supervisors to the police.

Indeed, it is all the duty of the General Election Commission and Election Supervisory Body to be able to act in various forms of socialization related to the conduct of general elections, so that all citizens can have a definition of an election which is democratically created. The General Election Commission and General Election Supervisors can also carry out an enforcement in violations of the election. while the KPU and Bawaslu cannot carry out their respective duties but are assisted by other parties in enforcing the rules in elections, including from the police, the Attorney General's Office and from the institutions of a court.

In enforcing the rules of a general election law there must be a clear arrangement that is not confusing or dubious. Not only arrangements that are clearly regulated and not doubtful, even from a law enforcement officer must have a constructive vision and mission with the same goal, namely to uphold the law in 


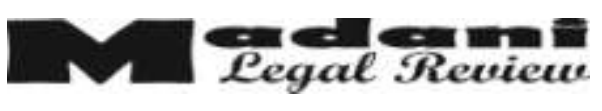

general elections. Not only seen from a vision and mission, but participants participating in law enforcement also need to have similarities in knowledge and understand the contents of election regulations. And now there is a lot of misunderstanding about Tupoksi that occurs from among the participants themselves. This is an obstacle in the implementation of general elections that have also occurred in 2014.

The implementation of elections is direct, fair, comprehensive, closed, and also honestly, it is all the desire of the implementation which is expected to run optimally. The implementation of good and quality general elections will be able to increase the degree of competition that is healthy, participatory, and representative which is stronger and more accountable. It is not only the synergy of the institution that functions as law enforcement, it turns out that in the field there is also often a dispute between parties from an organizer, which in the dispute the institution collides with an argument that shows itself as the highest party of the other party in doing best performance. Whereas in terms of aspects it is sufficient to provide an explanation that the position between the institution and the organizer has the same position. In this case it is certainly necessary for an understanding as well as preparation in carrying out their duties and authority in carrying out their respective duties, all of which are solely for the sake of good and correct elections.

In this matter they are not only asking to be able to properly correct their own duties, but can find out the location or changes of other institutions. This can change a competition into cooperation in supporting one another. Regarding problems in enforcing the law in general elections, it does not end here, some judicial institutions that can be recognized as having the authority to settle a rule in violation of the law, and often differences in a decision, for example in the cancellation of legislative candidates in general elections in Malang in 2014 because the KPU decided an illegal case that assumed that the candidate did not commit an offense from the Surabaya Administrative Court, which was very clearly contrary to the decision of the Malang District Court of Justice which had been decided previously. In the contents of the decision on the person concerned is proof that he has committed an offense. This kind of thing that can make legal certainty sourced from law enforcement becomes a question, is the regulation unclear? Or human resources that don't understand the contents of the regulations? 


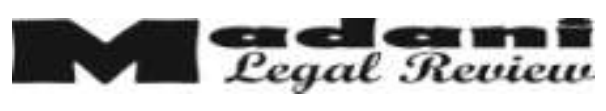

In accordance with the decision of the Constitutional Court No. 14 / PUU-XI / 2013 which will be held at the same time as general elections in 2019 until the end as long as the provisions of the Act require. As well as what Ali Safa'at and his colleagues said that as the simultaneous elections took place in Indonesia there will be a number of analyzes relating to future implementation. The most important thing is that in carrying out the elections simultaneously it can have an impact on the administration that becomes complicated. ${ }^{8}$

Therefore, in the process of law enforcement, the community is needed to be a supervisor in implementing law enforcement in general elections, so the community can not only be critical but also be able to play an active role in the process of law enforcement. From the previous explanation or elaboration above, there are a number of issues that will be discussed on how to do the law enforcement in general elections in 2014 ?; what are the weaknesses in the election law enforcement in 2014 ?; and what concepts will be used to improve election law enforcement in 2019?

8 Ali Safaat, et.al, Transformasi Model PemiluSerentak Di Indonesia Tahun 2019 PascaPutusan MK Nomor 14/PUU-XI/2013, JurnalFakultasHukumUniversitasBrawijaya

\section{DISCUSSION}

\section{Law Enforcement of General Elections in Indonesia}

Many argue about the legal system, Friedman himself said the legal system contained in the substance of the law or also called substance, and legal structure (structure) and cultural law (culture). Meanwhile, according to SoerjonoSoekanto himself said that law enforcement is an activity of equating or matching relationships in values that are exposed in strong rules and manifest in an attitude that conducts a series of explanations of the value of the final process, to create, maintain, and maintain harmony in society. ${ }^{9}$ Meanwhile SatjiptoRahardjo also said that in people's lives a law enforcement can / can be done concretely. ${ }^{10}$ In this case, of course there are factors that can influence the factors of sustenance, structure in law enforcement, and supporting facilities, as well as society and culture. ${ }^{11}$ In a section that supports factors from the core of electoral law, namely legislation in elections. In 2014 using legislation contained in:

a. In the implementation of general elections listed in Law No. 15 of 2011

\footnotetext{
9 SoerjonoSoekanto, Faktor-faktor yang MempengaruhiPenegakanHukum, Raja GrafindoPersada, Jakarta, 2005, p.5.

10 SatjiptoRahardjo, IlmuHukum, Citra AdityaBakti, Bandung, 1991, p. 181.

11 SoerjonoSoekanto, Op.Cit. p. 8.
} 


\section{$M$}

b. General Elections of Members of the DPR, DPD and DPRD are listed in Law No. 8 of 2012

c. Whereas in the election of the president and vice president in the Law No. 42 of 2008.

In the Law stated above, there are also regulations issued by the General Election Organizers, namely in the regulations of the KPU and Bawaslu. In the election law enforcement regulations themselves, namely, in violations of election crimes, election administration, as well as norms and principles in elections.

Article 260 of Law No. 8 of 2012 states that a criminal act is a violation or / and a crime in a criminal act of the general election stated in Law No. 8 of 2012. Whereas in Article 253 Law No. 8 of 2012, regarding violations of election administration that are violated can include the implementation, and mechanisms related to elections and violating norms and principles in elections. Meanwhile in the formulation of the code of conduct itself formulated in article 251 of Law No. 8 of 2012 which states in violating ethics in the conduct of general elections guided by oaths and promises as organizers of general elections.

\section{Legal Enforcement of General Election Laws}

In a settlement of a crime in the general election of the DPR, DPD and DPRD which is officially carried out by the general court, in Law No. 8 of 1981 in the explanation of the Criminal Code, unless determined by the others listed in Law No. 8 of 2012. And what applies is the principle of Lex Derogate Specialist LexGeneralis which states that a provision that is of a special nature can override provisions that are of a general nature. Special provisions for yautu are the position of Law No. 8 of 2012, the provisions must take precedence over the provisions of the Criminal Code. In special provisions a criminal offense refers to the specified time handle in resolving a criminal act. From the provisions of the time given it turns out to be shorter than the settlement of criminal offenses in general. The Criminal Code requires a maximum of only 51 days in its completion. The process of time needed to resolve the problem of crime is as follows: 


\begin{tabular}{|c|l|c|}
\hline No & Process & $\begin{array}{c}\text { Estimated Time } \\
\text { (Time Needed) }\end{array}$ \\
\hline 1 & $\begin{array}{l}\text { There is a report to the Election Supervisor about a finding that } \\
\text { occurred }\end{array}$ & $\begin{array}{l}7 \text { days } \\
\text { follow-up of the Election Supervisor }\end{array}$ \\
\hline 3 & From the police & 14 days \\
\hline 4 & From the prosecutor's office & 5 days \\
\hline 5 & $\begin{array}{l}\text { The inspection process is up to the decision of the District } \\
\text { Court }\end{array}$ & 3 days \\
\hline 6 & Appeal through the District Court & 3 days \\
\hline 7 & Delegation to the High Court & 51 days \\
\hline 8 & The inspection process reaches an appeal in the High Court \\
\hline & The amount of time needed to handle election violations & \\
\hline
\end{tabular}

Source: UU No. 8 Tahun 2012

We can see from the table, that the time given for handling a violation in the general election is quite short, this can result in the handling of passing the specified time period there will be a cancellation on the basis of law, it can easily not can continue the action. In this process, it is also a crucial stage in the holding of general elections, namely the stages in the campaign, which substantially constitutes the many problems in formulating editorials. Prohibition on campaign actions contained in Law Number 8 of 2012. There is complexity in the application of articles governing general election campaigns that must be examined. It would be better if we discussed the description of the rules in the implementation of the campaign by law which could cause complexity when connected with concrete legal events, such as what had happened in Malang. In an education there is a norm stated in article 86 (1) letter $\mathrm{h}$ which violates the norm in the campaign, saying that in an implementation, participants and officers are prohibited from using government facilities or places of education. Meanwhile the criminal provisions are very clearly written in article 299 of Law No. 8 of 2012, which reads: "an executor, participant, or campaign officer intentionally commits a violation in the conduct of general elections, as referred to 


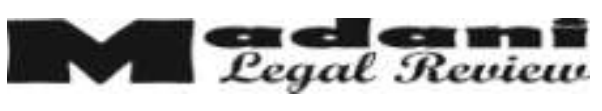

can be explained in article 86 paragraph 4 , affirming: a provision stated in paragraph 1 letter c, f, g, I and j, and in paragraph 2 it is also a criminal act in the general election as well.

There are times when events do not have to be regulated by law only, and there are times when events can be regulated by law. How to consider is one way to find the law. If a particular event is arranged in the law only to determine certain things in the event itself, and for other events the opposite is true. This method is commonly referred to as the acontrario method, which is an explanation of an event regulated in legislation. Article 86 paragraph 4 can also be said as a violation of a criminal act of general election as only as its provisions are listed in article 86 paragraph (1) letters c, f, g, i, j, which are also listed in article 86 paragraph (2).

In the use of this method, there will be contradictions in the provisions of Article 299 of Law No. 8 of 2012 states that in the provisions of article 86 paragraph (1) h, namely violations that are qualified for criminal offenses in general elections accompanied by threats of punishment. Opinions from Soedikno to treat analogies and a contrario can often be said in the method of interpretation. Legal reasoning or can also be referred to as an analogy and a contrario that contains reasoning, redenering, and argumentation. But in this method it is not an argument in justifying a rule, but rather to fill in the incompleteness of legislation. ${ }^{12}$ As stated in Article 299 of Law Number 8 Year 2012 which states that the provisions of article 86 paragraph (1) letter h, namely the views derived from argument a contrario is a criminal offense in general election. In perludem's notes, there are weaknesses in the regulations of the law minister which result in the obstruction of the law enforcement system, as follows:

a. The number of definitions about the campaign

In article 1 (29) Law No. 8 of 2012 provides a define about the campaign that the campaign is an activity of the participants of the election to be able to compete to convince the people by explaining a vision and mission and the program to be carried out. In his understanding of a law enforcer, especially the police, the campaign itself is understood in many ways to be a comparison: starting from the vision, mission, and program for the people, it is delivered in a clear and tangible manner, both in print media and electronic media such as television, radio, and so on. Therefore if an element in the campaign cannot be done, then the campaign will not

\footnotetext{
12 SudiknoMertokusumo, MengenalHukum, 2009, p. 71.
} 


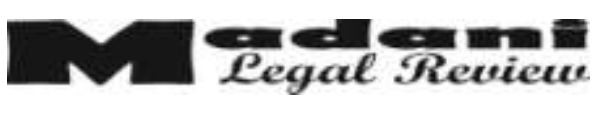

be said to be a campaign. A plan in his assignment later, the campaign submitted must be the same as the one deposited with the General Election Commission (KPU). If there is a campaign that conveys its vision and mission as well as its work program, but it is not in accordance with what is deposited with the electoral commission, then the submission is deemed invalid. But it does not rule out the possibility that it will be qualified as a violation, because there are differences in perceptions of understanding between the police and the institutions of the electoral supervisors.

b. Evaluating articles for money politics penalties

Negotiation or formulation in article 90 of Law No. 8 of 2012 which reads: "Court decisions that have obtained permanent legal force against violations as referred to in article 88 which are subject to election campaign implementers who are candidates for DPR, DPD, provincial DPRD, and district / city DPRD are used as the basis of the KPU, Provincial KPU, and regency / city KPU to take actions in the form of: a). cancellation of names of candidates for DPR, DPD, provincial DPRD and regency / city DPRD from the list of permanent candidates; or $b$ ). the cancellation of the application of candidates for DPR, DPD, provincial
DPRD and regency / city DPRD as elected candidates. "

In evaluating article 90 and article 88 , which reads: "in the event that there is sufficient preliminary evidence of a violation of the prohibition on election campaigns as referred to in article 86 paragraph (1) and paragraph (2) by the executor and participants of the election campaign, the KPU, Provincial KPU, and district / city KPU impose sanctions as stipulated in this Law. In Article 88 further also refers to article 86 paragraph (1) and (2). "

In order to be more strict in regulating the presence of participants or executors in promised gifts in the form of money or goods to be able to influence voting rights, article 90 should refer directly to article 86: "In the event that the election campaign is proven promising or giving money or other things as reward the election campaign participants directly or indirectly for: a). do not use their voting rights; b). use their voting rights by choosing election participants in a certain way so that their ballots are invalid; c). choosing certain political parties participating in the election; d). select prospective members of the DPR, provincial DPRD, district DPRD or certain cities; or e). choosing a particular DPD 


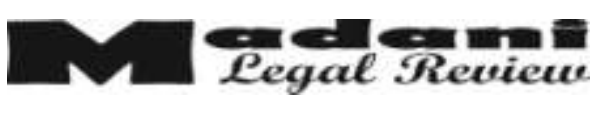

member candidate will be subject to sanctions as stipulated in this Act. "

c. Determination of actors in inconsistent money politics

The strength of money politics, so that in Law No. 8 of 2012 also has a weak point about giving sanctions to perpetrators of money politics. Article 86 also regulates the prohibition of campaigns, but many subjects, among others, still violate regulations that are made so that if they commit a violation as in a violation of money politics, the subject will be subject to sanctions. Article 88 affirms that there are only implementers and participants, while in article 90 states that if the participant is a state institution, then the write-off procedure as a candidate or cancel is inaugurated. The fundamental weakness of a formulation confirms that there is no intention from the law to provide explicit regulations so that it can ensnare the perpetrators who commit crimes in money politics.

\section{Legal Substance in Election}

\section{Administration Arrangements}

In electoral administration there is certainly a violation committed by a party, where the law itself in its enforcement is still not firm, this is because the sanctions given do not have any effect on the perpetrators so that they do not give the effect of the perpetrators who do it. The result will continue to be a possibility that will occur continuously. Not only inside but outside there are also violations as happened in the field, the KPU is not sufficiently obedient in carrying out its duties to immediately impose sanctions on violators of acts of election. in fact in its duties, the KPU is not tasked with giving sanctions to the perpetrators, but the KPU only gives reports.

\section{Analysis of Law Enforcement Structure and Culture}

In the enforcement of electoral criminal law there are institutions that are authorized in the law enforcement process, including: general justice, police chief, prosecutors, administrative court, and the Constitutional Court. In law enforcement for general elections, it is still in one room in the enforcement of criminal law, which includes the Election Supervisory Committee, the police, prosecutors and other agencies. Parties who are given assignments in laws and regulations with the aim of handling and resolving a problem in the law, which is a basic task of the legal apparatus.An integrated law enforcement listed in law No. 8 of 2012 consisting of Banwaslu, police, and prosecutors. The creation of integrated law enforcement is solely to create a formula 


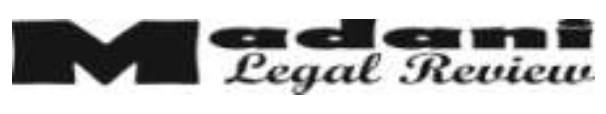

that refers to the process of investigating violations and prosecutions in renewal. The police tend to want from the reporting party, including complete evidence. However, to be able to provide complete evidence, it is quite difficult for the election supervisor, because the collection of proof files is quite time consuming.

Meanwhile, in the legal culture, at the election stage, the campaign stage, the voting stage, it all relates to the community. Culture in society requires the willingness and courage to create law enforcement and if a violation occurs, the community must be brave enough to report it.

\section{Refinement of General Election Legal Substances}

To be able to handle a violation, it requires a period of time that is applied selectively, to make it more detailed in data collection so that Bawaslu has time to be able to complete data that is considered incomplete which will later be submitted to the police and to give weight or light sanctions to qualified crime. Related to Law No. 15 of 2011 concerning electoral violations which is a difference in the term of office imposed by the election organizer, such as the KPU which has a term of 5 years while Bawaslu is usually formed several months before the implementation. This triggers the ego.

In this difference in terms of office, it can affect the expertise of the Election Supervisory Committee, because it does not have a period of time to be able to explore strategies as well as supervisory material that must be possessed as a supervisor. Because after all, a supervisor must be more expert or have their own abilities, so that there are no more violations that occur due to lack of experience of the supervisor.

In addition to this, in terms of penyempuranaa, a strategy in supervisory institutions is also needed for strengthening legal structures. As explained in Law No. 8 of 2012 which said that as an election supervisor it was authorized to recommend a violation to the $\mathrm{KPU}$, in the implementation of the future the Supervisory Committee must grant authority over the decision in the violation of election administration. In strengthening the election supervisory institutions are assisted by the police with investigations in violations of election participant administration. In this investigation, it is expected to facilitate the completion of the evidence and the required files. In article 267 paragraph (1) Law No. 8 of 2012 reads: "To equalize the understanding and pattern of handling criminal acts of 


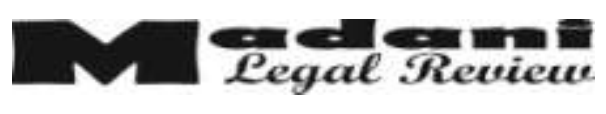

elections, the Election Supervisory Body, the police, the Attorney General's Office form an integrated law enforcement center".

In the 2019 general election the legislative and election elections of the president and vice president will be put together in the implementation, so that later in the implementation it will guarantee a more legal certainty and also in its enforcement. It can be said that the general election in 2019 is simultaneous elections between two different types of elections, so the formulation of a law is formulated in an integrity manner to be able to minimize the contradiction between the two. Efforts can be made to damage the legislative and presidential election rules, namely in a unified law. If the two regulations are separated in separate laws, there will be risks for both. And if one of them is formulated first and immediately stipulated in legislation, it can lead to inconsistencies, with the future laws and regulations. It is not denied that the two are related to one another in the logical consequences of the union between legislative elections and presidential elections.

\section{CONCLUSION}

Organizing institutions in general elections not only need a synergy, but need a similarity in vision and mission, as well as understanding in the knowledge of regulations in elections between institutions such as organizers of elections, police, prosecutors, and judicial institutions. In their duties, these institutions are not only demanded in terms of function and position because they also need to be aware of the location and tasks of other institutions for the creation of orderly elections and the absence of violations in their implementation. To create a change of reinforcement in the institutions of supervisory elections and legal substance in general elections. Actually, not only the structure and substance that needs to be made an improvement, but the culture that exists in the community can also determine, with these three combinations, there will be involvement in the process of implementing general elections as a whole with the law enforcement process. In the general election which was held at the time in 2014 the aspects of law enforcement were still weak for the future need to be improved so that the election of an institution such as the DPR, DPD and DPRD and in the presidential and vicepresidential elections will also be held together- the same or simultaneously in the upcoming 2019. 


\section{REFERENCE}

Soekanto,

Soejono.

PengantarPenelitianHukum.

Jakarta:Universitas Indonesia, 2014.

Wiyanto, Roni. PenegakanHukumPemilu DPR, DPD, DPRD.Bandung: MandarMaju, 2014.

\section{Journal Article}

Manalu,

RantoMulyadi.

"EfektivitasTugasLembagaPenegak anHukumTerpadu Kota

PekanbaruDalamPemilihanUmumT ahun 2014 BerdasarkanUndangUndangNomor 8 Tahun 2012 TentangPemilihanUmumDewanPer wakilan Rakyat DewanPerwakilan Daerah Dan DewanPerwakilan Rakyat Daerah Tahun 2014”, JomFakultasHukum, Volume 2, Nomor 2, 2015, hlm. 1-15. Mangiri,

Irfandi.

"TinjauanYuridisTerhadapTindakP idanaPemilu", JurnalImuHukum Legal Opinion, Volume 1, Nomor 1, 2013, hlm.1-10.

Chrisdanty, Febry. "Review Pemilu 2014 MenyongsongPemilu 2019 Ditinjau Dari

AspekPenegakanHukumPemilu", MaksigamaJurnalHukum, Volume 3, Nomor 1, 2016, hlm. 43-57.

Junaidi,

Veri;

Ramadhanil,

FadlidanFirmansyah,

Arifin."EvaluasiPenegakanHukum

Pemilu 2014", YayasanPerludem, Jakarta.

Ali Safaat, dkk. "Transformasi Model PemiluSerentak Di Indonesia Tahun 2019 PascaPutusan MK Nomor 14/PUU-XI/2013”, Jurnal:

UniversitasBrawijaya

Democracy and the Rule of Law in Contemporary China, 2017

Anthony Arblaster: Democracy, translated by Sun Rongfei et al., Jilin People's Publishing House, Changchun, Jilin Province, 2005 edition, p. 19.

Merle, Patrick dan Dennis Patterson.(2014). "The French parliamentary and Presidential elections of 2012", Notes on Recent Elections/Electoral Studies 34 (291-379).

\section{Laws and Regulations}

KitabUndang-UndangHukumPidana (KUHP)

PeraturanUndang-UndangNomor 8 Tahun 2012 TentangPemilihanUmum.

PeraturanUndang-UndangNomor 15 Tahun 2011

TentangPenyelenggaraanPemilihan Umum 
